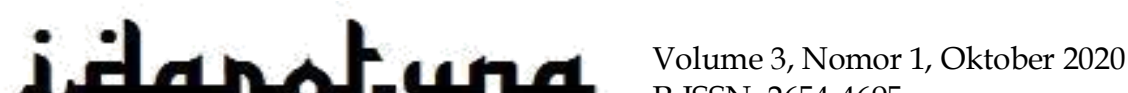 \\ P-ISSN: 2654-4695 \\ E-ISSN: 2654-7651 \\ Jumal Kajian Manajemen Dạkwah . DOI: 1010.24014/idarotuna.v3i1.
}

\section{Wajah Ekonomi 4.0: Perbankan Syari'ah Digital, Peningkatan Daya Saing Dan Strategi Dakwah Islam}

\author{
Fathayatul Husna ${ }^{1}$ \\ ${ }^{1}$ Universitas Islam Negeri Ar-Raniry Banda Aceh
}

\begin{abstract}
Industrial Revolution Era 4.0 as an era marked by the massive movement of information technology development. The development of internet-based technology is reaping many discourses related to opportunities and challenges in the future. One of the most crucial fields in the era of the industrial revolution 4.0 is the financial sector which is closely related to the scope of banking. In Indonesia, banking does not only stand as a conventional one, but also provides space for the development of Islamic banking. In this article, the authors focus on academic discourse on Islamic banking and digital transformation and increasing competitiveness. The author uses descriptive qualitative methods with virtual ethnographic approach techniques and literature studies. The results of this paper explain how Islamic banking works by applying digital technology in the banking service system and its connection with Islamic Da'wah practice.
\end{abstract}

\section{Keywords: Syariah Banking, Digital, Competitiveness.}

Abstrak:Era Revolusi Industri 4.0 sebagai era yang ditandai dengan masifnya gerakan perkembangan teknologi informasi. Berkembangnya teknologi berbasis internet menuai banyak diskursus terkait peluang dan tantangan di masa depan. Salah satu bidang yang paling krusial dalam era revolusi industi 4.0 ini adalah bidang keuangan yang erat kaitannya dengan lingkup perbankan. Di Indonesia perbankan tidak hanya berdiri tunggal sebagai konvensional, tetapi juga memberikan ruang berkembangnya perbankan syariah. Dalam artikel ini, penulis fokuspada diskursus akademik mengenai perbankan syariah dan transformasi digital serta peningkatan daya saing. Penulis menggunakan metode deskriptif kualitatif dengan teknik pendekatan virtual etnografi dan studi literatur. Hasil tulisan ini menjelaskan bagaimana berjalannya perbankan syariah dnegan menerapkan teknologi digital dalam sistem pelayanan perbankan serta kaitannya dengan praktik dakwah Islam.

\section{Kata Kunci:Perbankan Syari’ah, Digital, Daya Saing.}

\section{Pendahuluan}

Dalam jangka dua dekade ini, perkembangan teknologi semakin berkembang dan bertransformasi ke berbagai ragam serta fungsinya. Seperti, hadirnya sejumlah terobosan aplikasi hiburan menambah warna baru bagi para penggunanya. Tidak hanya di bidang hiburan, teknologi digital juga dimanfaatkan untuk menunjang nilai positif di ruang publik. Perkembangan ini dinilai menciptakan gerakan fungsi yang sangat dinamis diberbagai sektor (Tazkiyyaturrohmah \& Sriani, 2020). Sehingga, teknologi menjadi bagian dari kebutuhan primer dalam melancarkan aksi serta strategi dari masing-masing bidang.

Revolusi teknologi dan informasi menawarkan sejumlah kemudahan bagi masyarakat dari berbagai kalangan. Pemanfaatan teknologi ini sudah banyak digunakan oleh berbagai 
instansi pemerintahan, institusi swasta, perdagangan, pendidikan, bisnis, dan di berbagai sektor lainnya. tawaran kemudahan ini akan memudahkan setiap pekerjaan dan penyebaran informasi yang disampaikan oleh masing-masing pengelolanya. Dengan demikian, informasi diharapkan dapat tersalurkan secara merata kepada masyarakat yang membutuhkan. Tidak hanya itu, teknologi juga menawarkan bentuk-bentuk inovasi terbaru dalam penggunaan fasilitas. Misalnya, hadirnya sejumlah gadget dan ragam aplikasi pendukung untuk dinikmati oleh para penggunanya. tidak sampai disitu, teknologi juga berperan aktif untuk meningkatkan pendapatan negara. Oleh karena itu, perekonomian menjadi salah satu sektor terpenting yang sangat membutuhkan pemanfaatan teknologi mutakhir.

Salah satu sektor perekonomian yang sangat membutuhkan penggunaan teknologi adalah industri perbankan. Terkait hal ini, dalam dunia perbankan dikenal dengan istilah financial technology atau teknologi finansial. FinTech dikenal sebagai bentuk inovasi di bidang finansial yang telah menggunakan perangkat teknologi untuk memudahkan pelayanan finansial (Winasis

\& Riyanto, 2020). Lahirnya FinTech di sistem perbankan menunjukan bahwa telah berkembangya revolusi industri menjadi 4.0. Seperti yang telah diketahui bahwa industri 4.0 sangat mempengaruhi seluruh aktivitas dengan pemanfaatan teknologi secara masif (Winasis \& Riyanto, 2020). Bank Indonesia juga mendefiniskan FinTech sebagai bentuk inovasi baru dengan madukan jasa keuangan dan teknologi (Rianto, Bukhari, \& Fikri, 2020). Dengan demikian, konsep FinTech ini dipadukan dalam industri perbankan untuk melahirkan konsep-konsep baru dalam memfasilitasi proses transaksi keuangan yang lebih praktis.

Adanya layanan keuangan seperti digital banking, online digital insurance, payment channel system dan lain sebagainya merupakan bagian dari layanan pemanfaatan teknologi dalam perbankan (Rianto et al., 2020). Layanan berbasis teknologi ini diharapkan dapat menumbuhkan taraf operasional dan mutu pelayanan perbankan bagi masyarakat. Teknologi dinilai perlu untuk dimanfaatkan di ranah perbankan disesuaikan dengan berkembangnya penggunaan teknologi di kalangan masyarakat.

Penggunaan teknologi berbasis iternet di Indonesia diperkirakan akan semakin bertambah setiap tahunnya. Statistia melalukan sebuah riset yang menunjukkan proyeksi pengguna internet di Indonesia pada tahun 2018 mencapai 95,2 juta dan pertumbuhannya diperkirakan akan meningkat sebesar 10,2\% pada periode 2018-2023 (Jayani, 2019). Berdasarkan data ini, tidak heran jika Indonesia berhasil menduduki peringkat ketiga pengguna internet di lingkup Asia setelah Tiongkok dan India (Kusnandar, 2019). Hal ini menunjukkan internet menajdi salah satu atribut penting yang digunakan oleh mayoritas warga negara di Indonesia. Seperti yang telah disinggung sebelumnya, masyarakat Indonesia menggunakan internet untuk mendukung sejumlah bidang yang digeluti, salah satunya adalah bidang perbankan.

Transformasi penggunaan digital di perbankan dinilai sedikit terlambat dibandingkan dengan negara-negara lainnya (Winasis \& Riyanto, 2020). Bank Indonesia menilai bahwa aksi ekonomi digital yang diwujudkan oleh industri perbankan masih dalam tahap pengembangan. Hal ini dikarenakan rendahnya minat masyarakat untuk beralih pada inovasi ekonomi digital (LSPP, 2018). Tercatat masih sekitar 35\% dari masyarakat Indonesia yang telah menggunakan 


\section{Universitas Islam Negeri}

Sultan Syarif Kasim Riau
Idarotuna: Jurnal Kajian Manajemen Dakwah Vol. 3 No. 1. Oktober 2020: Hal 59-70

jasa keuangan digital. Selain rendahnya minat masyarakat dalam menyikapi pembaruan ekonomi digital ini, alasan lainnya muncul berupa kekhawatiran akan keamanan informasi di ruang digital (LSPP, 2018). Alasan-alasan seperti ini tentu menjadi perhatian penting pada sejumlah otoritas industri perbankan untuk berkompeten meluncurkan produk ekonomi baru di ranah digital.

Perbankan di Indonesia tetap berupaya maju menciptakan sejumlah layanan produk berbasis digital untuk kemudahan dan kesejahteraan masyarakat sesuai dengan aturan yang berlaku. Dalam dunia perbankan di Indonesia, Bank Indonesia berdiri sebagai induk dari sejumlah bank lain (Bank Indonesia, 2020). Untuk memelihara kestabilan nilai rupiah, Bank Indonesia sangat memperhatikan proses keuangan terhadap jasa dan barang serta terhadap mata uang negara lain.

Dalam menjalankan fungsinya, Bank Indonesia juga memberikan perhatian penuh pada strategi perbankan konvensional dan syariah (Alamsyah, 2012). Terkait hal ini, pihak Otoritas Jasa Keuangan (OJK) masih mencatat bahwa produk dan layanan perbankan syariah masih berada satu tingkat di bawah perbankan konvensional (S. B. Fatimah \& Hendratmi, 2020). Meskipun demikian, Bank Indonesia ikut mendukung perketumbuhan laju perbankan syariah untuk membawa "maslahat" bagi peningkatan kesejahteraan masyarakat. Beberapa poin penting yang menjadi landasan dukungan Bank Indonesia kepada perbankan syariah di antaranya (Alamsyah, 2012), pertama, perbankan syariah dinilai memiliki kedekatan yang lebih nyata pada setiap produk-produknya,. Kedua, perbankan syariah dinilai memiliki daya tahan yang kuat meskpiun berada pada masa krisis. Ketiga, ruh syariah lebih terjaga lewat sistem bagi hasil, sehingga strategi ini dinilai menawarkan konsep adil bagi semua kalangan.

Terkait perkembangan perbankan syariah, sejumlah bank syariah juga telah memanfaatkan tekologi untuk menciptakan produk digital. Misalnya, seperti layanan nternet banking, mobile banking, phone banking, dan sebagainya. Upaya ini menjadi tolak ukur melesatnya angka pertumbuhan perbankan syariah di Indonesia. Hal ini dapat dilihat banyaknya sejumlah perbankan syariah muncul di ruang publik, di antaranya sebanyak 11 Bank Umum Syariah (BUS), 24 Unit Usaha Syariah (US) dan 155 BPRS (Alamsyah, 2012).

Diskursus akademik mengenai perbankan syariah, digital dan daya saing telah diteliti oleh sejumlah sarjana, seperti Hani Werdi Apriyanti, Abdus Sama DZ., Siti Bunga Fatimah dan Achsania Hendratmi, Nori Ayufi, dkk., dan Halim Alamsyah.

Abdus Salam Dz menjelaskan bahwa kualitas perbankan syariah perlu dibeikan perhatian lebih fokus (Dz, 2018). Salam menilai pangsa pasar bank syariah masih teratat sebagai kategori rendah.Optimalisasi digital sangat mendorong lahirnya produk dan layanan inovasi baru untuk meningkatkan kepercayaan masyarakat dan para nasabah. Namun, tetap memprioritaskan keamanan para penguna jasa bank syariah degngan baik.

Senada dengan Salam, Hani Werdi Apriyanti, Siti Bunga Fatimah dan Achsania Hendratmi juga menjelaskan bahwa industri perbankan syariah akan semakin berkembang jika memanfaatkan teknologi dengan bijak (S. B. Fatimah \& Hendratmi, 2020). Keduanya juga menjelaskan generasi digital menjadi sasaran utama yang harus diprioritaskan oleh perbankan syariah. Generasi digital sangat membutuhi keamanan privasi dalam sistem perbankan digital. 
Oleh karena itu, sistem perbankan syariah dalam platform digital perlu tindakan kewaspaan tinggi (Apriyanti, 2018).

Berbeda dengan beberapa sarjana di atas, Nori Ayufi, dkk., menjelaskan bahwa tahapan penggunaan teknologi pada perbankan suda memasuki tahap pemberdayaan (empowerment) (Ayufi, Pertiwi, Shabrina, \& Irwansyah, 2019). Salah satu bank di Indonesia telah mengoptimalkan layanan produk berbasis digital dan pemberdayaan. Layanan ini diciptakan dengan memunculkan 4 elemen penting, seperti dialogue, access, risk assesment dan transparency. Elemen ini akan menghasilkan interaksi dalam komunitas online (online community) yang diharapkan hadir interaksi komunikatif (Ayufi et al., 2019).

Kemudian, Halim Alamsyah juga menjelaskan bahwa wajah perbankan syariah di Indonesia semakin gemilang di tengah publik. perbankan nasional dinilai berhasil mendorong berkembangnya perbankan syariah di Indonesia. Salah satu faktor pemicu berkembangnya perbankan syariah adalah dengan mengoptimalkan penggunaan bantuan digital. Selain itu, program edkasi dan sosialisasi kepada masyarakat juga turut menambah popularitas perbankan syariah di kalangan masyarakat.

Berdasarkan beberapa hasil penelitian di atas dapat diketahui bahwa memanfaatkan digital pada sistem perbankan syariah dapat mendukung akselerasi pertumbuhannya di Indonesia. Di samping meningginya taraf perbankan syariah di muka publik, digital juga menghadirkan sejumlah tantangan lainnya yang harus dihadapi oleh perbankan syariah. Oleh karena itu, penulisan artikel ini akan meneruskan hasil penelitian para sarjana terdahulu. Dalam penulisan artikel ini, penulis akan fokus pada diskursus akademik mengenai wajah baru ekonomi 4.0, digital-baking syariah dan peningkatan daya saing. Artikel ini setidaknya mencoba menjawab dua pertanyaan sederhana, yaitu: Bagaimana perjalanan evolusi perbankan syariah? Bagaimana digitalisasi banking perbankan syariah, pencapaian daya saing dan kaitannya dengan praktik dakwah Islam?

\section{Metode}

Penulisan artikel ini disajikan dengan menggunakan pendekatan deskriptif kualitatif. Penulis menyajikan data dengan langkah pengumpulan informasi melalui secara virtual ethnography, yaitu mengamati pergerakan dan perkembangan wacana perbankan syariah di bebrbagai media online. hal ini dilakukan karena penulis memiliki keterbatasan dalam mengakses sumber informasi, dikhawatirkan karena tengah menghadapi pandemi covid-19. Selain itu, penulis juga mengumpulkan data melalui studi literatur untuk memperkaya data akademik. Oleh karena itu, langkah dengan cara virtual ethnography dan studi literatur menjadi langkah penting untuk mewujudkan tulisan ini.

\section{Hasil dan Pembahasan \\ Evolusi Perbankan Syariah}

Salah satu bentuk strategi yang dilakukan pemerintahan Soeharto mendukung kembali gerakan Islam adalah dengan mengizinkan berdirinya perbankan syariah di Indonesia. hal ini 
dilihat dari hasil amandemen UU no. 7 tahun 1992 menjadi UU No. 101998 yang menetapkan bahwa hukum perbankan di Indonesia telah disahkan menganut sistem perbankan ganda (dual banking system). Kebijakan ini memberikan arahan secara penuh kepada bank-bank konvensional untuk membentuk layanan syariah melali Unit Usaha Syariah (UUS) (Syukron, 2013). Kemudian, aturan lainnya juga telah disahkan dalam UU no 23 tahun 1999 tentang Bank Indonesia. dalam aturaN ini Bank Indonesia diberikan amanah untuk dapat mengendalikan moneter berdasarkan aturan prinsip syariah (Syukron, 2013). Namun, di balik pengesahan aturan-aturan mengenai layanan syariah, perbankan syariah sudah terlebih dahulu hadir di Indonesia pada tahun 1991, yaitu berdirinya Bank Muamalat Indonesia. Bank ini adalah satusatunya bank yang menerapkan aturan bagi hasil. Tetapi, bereirinya bank syariah ini dinilai masih sangat lemah dalam landasan hukum (Syukron, 2013). Sehingga, aturan yang berlaku belum dapat dijalankan secara maksimal.

Setelah diberlakukannya aturan sah mengenai regulasi perbankan syariah, kegiatan perekonomian di Indonesia diharapkan dapat berjalan dengan baik dan bijak. Salah satu bukti dampak dari berdirinya perbankan syariah adalah konsistensi tetap berjalannya layanan keuangan syariah saat gejolan krisis moneter terjadi pada tahun 1997 (Syukron, 2013). Faktanya, operasional perbankan syariah dilaksanakan sesuai dengan kaidah larangan bunga bank ( riba). Tidak transparan (gharar) dan spekulatif (maysir). Elemen-elemen ini sangat diharapkan dapat menjadi tolak ukur bertahannya ketahanan ekonomi nasi di masa yang akan datang.

Pada tahun 2002, Bank Indonesia kembali memperbaiki aturan terkait unit usaha syariah melalui PMI Nomor 4/1/PBI Tahun 2002 yang secara umum mengatur tentang pemulihan bank konvensional menjadi cabang syariah dan pembukaan unit syariah di cabang konvensional (Syukron, 2013). Tidak berhenti di situ, perkembangan perbankan syariah semakin gesit dengan adanya kebijakan baru pada tahun 2006 yaitu dmengizinkan Bank Umum Konvensional yang telah memiliki Unit Usaha Syariah (UUS) untuk tidak perlu membuka kantor cabang (Syukron, 2013) Hal ini dilaksanakan agar dapat menghemat pengeluaran bank tanpa harus menyediakan infrastruktur baru.

Perbankan syariah di Indonesia dinilai mulai bergerak aktif sejak tahun 2008. Pada saat itu, perbankan syariah berhasil mencapai angka target sebesar Rp50 triliun (Syukron, 2013). Dampak adanya pencapaian ini membuat perbankan syariah sangat dikenal di kancah ASEAN, meskipun terhitung sedikit lambat dari negara tetangga. Kiat-kiat strategis dijalankan secara aktif, meliputi konsep positioning differentiation dan branding yang dilakukan oleh sejumlah perbanlan syariah. Bank syariah berusaha untuk dapat menerapkan kaidah Islam dan etika bisnis sebijak mungkin untuk mendapatkan meningkatkan taraf kepercayaan publik (Putritama, 2018).

Tidak berhenti sampai di situ, bank syariah juga sangat berinovasi untuk mengarahkan pelayanannya sebagai bagian pelayanan universal dan sampai pada seluruh lapisan masyarakat. Bank syariah berupaya menghadirkan produk-produk layanan sesuai dengan kategor dan segmen kebutuhan masyarakat. Oleh karena itu, dalam proses perkembangannya, bank syariah sangat peduli pada pembibitan kader atau sumber daya manusia (SDM). Strategi ini dilakukan agar SDM dapat memenuhi kepuasan nasabah secara bijak. 
Inovasi-inovasi terbaru menjadi jendela bangkitnya perbankan syariah. Seperti yang telah disinggung sebelumnya bahwa teknologi informasi saat ini telah menjadi pemenuhan kebutuhan primer di kalangan masyarakat. Teknologi informasi menjadi "habit" atau kebiasaan gaya hidup masyarakat di era milenial ini. Melihat perkembangan ini, bank syariah ikut berupaya melahirkan sejumlah layanan yang dipusatkan dengan bantuan teknologi informasi. Pemanfaatan teknologi informasi ini dijadikan sebagai alat untuk menyampaikan program sosialisasi dan edukasi terkait proses layanan bank syariah kepada publik (Syukron, 2013). Sehingga, diharapkan proses perkembangan bank syariah dapat diterima dengan baik oleh segenap masyarakat di seluruh belahan negeri (Syukron, 2013).

Kondisi perbankan syariah memang dinilai memiliki peningkatan setiap tahunnya. Namun, hasil yang didapatkan masih terbilang belum sesuai dengan yang diharapkan. Pada tahun 2015 harapan target yang akan dicapai sebesar 15\%, tetapi kenyataannya perbankan syariah hanya mampus mencapai target sebesar 4,85\% (Syukron, 2013). Kondisi ini mendorong Bank Indonesia dan para stakeholders perbankan syariah mcenari jalan keluar untuk mendukung ketahanan perbankan syariah di Indoensia.

Perbankan syariah sebagai bank dengan sistem pelayanan dan keuangan syariah tentunya sangat berpeluang besar untuk berdiri kuat di Indonesia. Hal ini dikarenakan Indonesia sebagai negara dengan jumlah penduduk muslim terbesar di dunia. Dominasi ini menjadi potensi berkembangnya nasabah di perbankan syariah. Dibantu dengan adanya fatwa mengenai operasional syariah dari pihak Dewan Syariah Nasional (DSN) dan Majelis Ulama Indonesia (MUI), menjadikan kualitas perbankan syariah di Indonesia menjadi

Kabar baiknya, pada tahun 2017 Otoritas Jasa Keuangan (OJK) mencatat bank umum syariah di Indonesia telah mencapai 13 bank, unit usaha syariah di bank konvensional mencapai 21 bank dan Bank Pembiayaan Rakyat Syarih mencapai 102 bank (Utama, 2018). Data ini menjadi bukti bahwa eksistensi perbankan syariah dinilai bergerak secara aktif dan positif. Di bawah pengawas negara, para lama dan pakar ekonomi Islam, menjadikan perbankan syariah lebih maju di setiap masanya, meskipun total asetnya masih terbilang lebih rendah dibandingkan bank konvensional.

Dengan demikian, inovasi-inovasi terbarukan sangat dibutuhkan untuk memberdayakan SDM di lingkungan perbankan syariah untuk menjadi jalannya perekonomian nasional menjadi lebih baik. Inovasi-inovasi ini dapat direlasikan sesuai dengan kebutuhan zaman di era digital ini. penyesuaian dilakukan dengan melihat kebutuhan gaya hidup masyarakat yang telah didominasi oleh penggunaan teknologi digital berbasis online.

\section{Financial Technology: Digitalisasi dan Pencapaian Daya Saing Perbankan Syariah}

Perkembangan dunia saat ini tidak dapat dielakkan dari gencarnya penggunaan teknologi informasi. Teknologi informasi tidak hanya mensasar publik dalam segmen tertentu, alat ini juga bergerak secara dinamis pada kalangan anak-anak dan remaja. Bahkan, data menunjukkan bahwa penggunaan teknologi informasi dikuasai oleh kalangan anak muda dengan rentang usia 20-35 tahun (Haryanto, 2019). Selain itu, desain yang ditawarkan juga disesuaikan dengan kebutuhan 
setiap kalangan dan usia. Dengan demikian, tidak heran jika pengguna teknologi informasi menjadi kebutuhan primer saat ini di era modern.

Menyinggung tentang kebutuhan primer, perkembangan teknologi informasi sangat mendukung setiap sektor yang dijalankan manusia. Tidak hanya memenuhi keinginan di bidang hiburan, teknologi informasi juga dapat memenuhi kebutuhan lainnya, seperti, berbelanja online, pembayaran online, kebutuhan kesehatan online, vote online dan ragam penggunaan lainnya. Sektor yang sangat menyita perhatian publik saat ini adalah berkaitan dengan sistem keuangan. Sektor ini menjadi bagian terpenting bagi kalangan masyarakat yang secara aktif melakukan transaksi secara online. oleh karena itu, perbankan mengadopsi pemanfataan teknologi informasi online untuk menjangkau publik.

Muhammad Richo Rianto menjelaskan bahwa perbankan menjadi salah satu sektor yang akan mengalami tantangan berat hadirnya teknologi (Rianto et al., 2020). Tantangan ini akan berimbas pada perubahan gaya hidup masyarakat yang didominasi oleh penggunaan internet. Hal ini juga akan mengakibatkan munculnya tantangan dalam industri perbankan untuk berinovasi lagi dalam mewujudkan kesejahteraan masyarakat dan menciptakan daya saing yang sehat dalam industri perbankan. Inovasi penggunaan teknologi informasi di industri perbankan disebut dengan Finansial Technology atau disebut dengan FinTech. FinTech ini dinilai sangat mempengaruhi aktifat masyarakat dalam mengelola keuangan. Tidak hanya kalangan pengguna, FinTech juga dimanfaatkan sebaik mungkin untuk menata tatanan dan sistem operasional perbankan.

Salah satu jenis FinTech yang dijalankan oleh perbankan adalah dengan menghadirkan $e$ money. Pada tahun 2009 Bank Indonesia menerbitkan e-money melalui Peraturan Bank Indonesia 11/12/PBI/2009 tentang uang elektronik (e-money) (S. Fatimah \& Suib, 2019). E-money menawarkan konsep kemudahan dalam melalukan transaksi. Tidak hanya itu, e-money juga dianggap dapat membant menjaga proteksi keuangan dalam bentuk fisik. Hal ini sangat menguntungkan para nasabah yang telah menggunakan teknologi informasi sebagai kebutuhan primernya.

Berdasarkan uraian di atas dapat dipahami bahwa perbankan telah melakukan strategi "melek" pada inovasi digital. Tidak hanya perbankan konvensional, strategi ini juga dilakukan leh industri perbankan syariah. Seperti yang telah disinggung pada subbab sebelumnya bahwa perbankan syariah kian berkembang pesat dengan hadirnya inovasi berbasis digital, meskipun total aset yang dimiliki masih terbilang berada di bawah total aset perbankan konvensional. Upaya memadukan program-programnya dnegan inovasi digital menjadi perbankan syariah tampil lebih berani di depan publik.

Secara umum, OJK mengklasifikasikan FinTech menjadi dua bagian, yaiti FinTech 2.0 dikhusus untuk pelayanan keuangan digital dan FinTech 3.0 untuk pengembangan startup teknologi dan jasa keuangan (Itg.id, 2019). Pada umumnya, pada industri perbankan menggunakan FinTech 2.0, misalnya Bank Indonesia memberikana layanan sistem pembayaran berupa Bank Indonesia Real Time Gross Settlement (BI-RTGS), Sistem Kliring Nasional BI (SKNBI) (Franedya, 2018). Hal ini menunjukkan bahwa teknologi menjadi alat penting dalam 


\section{Universitas Islam Negeri}

Sultan Syarif Kasim Riau
Idarotuna: Jurnal Kajian Manajemen Dakwah Vol. 3 No. 1. Oktober 2020: Hal 59-70

proses pelayanan keuangan di industri perbankan atau dikenal dengan istilah digital banking. Proses digital banking ini akan menggantikan cara-cara lama dalam melakukan layanan transaksi dan sistem operasional. Proses ini diharapkan akan memudahkan masyarakat untuk tetap dapat melakukan transaksi dengan mudah melalui smartphone.

Tidak hanya pada perbankan konvensional nasional, perbankan syariah juga menerapakan pemanfaatan teknologi digital dalam setiap produknya. Adopsi penggunaan teknologi digital pada bank syariah menjadi sebuah keunggulan untuk mendorong daya saing yang sehat dengan bank umum nasional (Fatahillah, 2018). Pemanfaatan teknologi digital tidak hanya sebata merubah pola transaksi dari cara lama menjadi digital, tetapi juga menjadi setiap elemen di dalamnya mengikuti perkembangan FinTech yang dinilai lebih baru. Perbankan syariah belum menjalankan pemanfaatan teknologi secara sempurna (Fatahillah, 2018).

Menyangkut wacana mengenai transformasi digital oleh perbankan syariah, dikabarkan sedang memasuki fase berkembang. Salah satu bank syariah di Indonesia, Bank BCA syariah, meluncurkan terobosan terbaru pada kanal elektroniknya (e-channel) berupa "klik BCA Syariah" (Hutauruk, 2020). Terobosan ini dilakukan untuk memperluas jangkauan dari program sebelumnya. Hal ini menunjukkan bahwa bank syariah sangat berupaya untuk mengoptimalkan pelayanan secara onlien. Selain itu, bank syariah juga membuka layanan internet banking seperti mobile banking.

Keterlibatan OJK dengan merancang kerjasama antara Bank Syariah dan FinTech dinilai dapat membawa perubahan pada peningkatan daya saing bank syariah. Kerjasama yang dibentuk adalah outsourcing platform dan shadow investor sumber (Sudarwan, 2019). Bentuk kerjasama pada skema outsourcing platform mengacu pada lebih terbukanya informasi kepada investor. Sedang skema shadow investor mengenai tawaran bank syariah proyek pembiayaan kepada investor melalui perusahaan FinTech yang dilakukan sedikit lebih tertutup. Hal ini dikarenakan bank syariah tidak igin disebutkan sebagai promotor penawaran projek kepada investor. Kedua skema dinilai sangat strategis untuk membantu mengembangkan daya saing pada perbankan syariah.

Bersamaan dengan pemanfaatan teknologi digital, perbankan syariah juga fokus pada layanan utamanya, yaitu Muudharabah Muqayadah. Klasifikasi prodk menjadi salah satu instrumen yang diharapkan dapat mendorong sebagai terobosan baru dalam dunia perbankan syariah (Sudarwan, 2019). Namun, tidak mudah untuk merubah seluruh tatanan dan sistem perbankan syariah dalam sesaat. Butuh uji coba pada kelayakan dan dampaknya pada sejumlah bidang.

Tentunya dengan mengandalkan pemanfaatan teknologi digital 4.0 ini, bank syariah akan berhadapan dengan dua kondisi sealigus, yaitu peluang dan tantangan. Peluangnya adalah perbank syariah berkesempatan untuk membangun SDM yang kreatif dan inovatif. Selain itu, penawaran khusus yang dirancang dengan landasan syariat Islam, akan mudah diterima di kalangan masyarakat, khususnya Muslim. dengan adanya teknologi digital ini juga akan mendorong terjalinnya kerjasama dan daya saing yang sehat antar perbankan syariah dan konvensional. 
Di samping hadirnya peluang secara terbuka, penerapan teknologi digital juga berpengaruh pada sejumlah tantangan masa depan (Tazkiyyaturrohmah \& Sriani, 2020). Tantangannya mengacu kepada tantangan Revolusi Industi 4.0 yang dikhawatirkan akan banyak mesin-mesin robot pengganti kinerja tangan manusia. Selain itu, perlu kewaspadaan dan kehatihatian yang tinggi untuk menjaga seluruh data nasabah dengan baik. Hal ini dikarenakan big data dyang telah tersusun secara sistemik dalam program, masih banyak yang kehilangan data akibat ulah tangan para hacker. Hal ini menjadi perhatian khusus dalam mewujudkan digital banking syariah.

Meskipun demikian, seluruh aturan perbankan syariah telah dibina dengan baik oleh Bank Indonesia (BI) dalam Peraturan BI nomor 19/12/PBI/2017 tentang Penyelenggaraan Teknologi Finansial. OJK juga mengawasi bisnis FinTech dengan baik yang telah tertuang dalam Peraturan OJK nomor 13/POJK/02/2018 tentang inovasi Keungan Digital di Sektor Jasa Keuangan dan juga Otoritas Jasa Keuangan. Dengan demikian, setiap program yang akan dijalankan oleh perbankan syariah melalui teknologi digital akan dipantau secara langsung oleh kedua lembaga otoritatif ini.

\section{Perbankan Syariah sebagai Media Dakwah}

Menerapkan prinsip syariat Islam dalam dunia perbankan, menjadi hal terpenting yang perlu diterapkan dalam setiap birokrasinya. Dalam beberapa penelitian menunjukkan adanya perdebatan di kalangan akademik terkait penting tidaknya penerapan syariah di perbankan. Misalnya, Budiono menjelaskan bahwa perbankan syariah tidak sepenuhnya menerapkan praktik syariat Islam, mereka hanya menampilkan Islam untuk menarik nasabah (Budiono, 2017). Sedangkan, peneliti yang lain menjelaskan bahwa perbankan syariah telah berupaya menerapkan nilai-nilai keislaman di dalamnya (Rohayati, 2019). Upaya ini dilakukan untuk memberikan kemudahan bagi setiap nasabah, khususnya muslim. tetapi juga tidak membatasi non-muslim untuk berlangganan di perbankan syariah.

Terkait praktik dakwah dalam perbankan syariah, sejatinya telah ditunjukkan melalui labelling syariah. Penulis berargumen lebelling syariah pada perbankan adalah tidak hanya sebagai upaya pemenuhan fasilitas keuangan syariah, tetapi juga juga bagian dari unsur dakwah. Terlepas bernilai profit atau tidak, praktik dakwah ini pasti dilakukan dengan berbagai cara, yaitu muamalah dengan pendekatan nasabah, muamalah dengan pendekaatan internal, dan mamalah denagn pendekatan stakeholders (Okyanta, 2017). Muamalah dengan para internal karyawan artinya memberikan pembelajaran kepada karyawan terkait pemeliharaan materi dan rohani. Para internal karyawan diberika motivasi untuk melakukan pekerjaan sebagai mungkin dan diniatkan untuk berjihad di jalan kebaikan serta menjadi pekerjaan perbankan syariah sebagai bagian dari tanggung jawab kepada keluarga.

Selanjutnya, muamalah dengan nasabah yaitu nasabah mendapat respon yang positif dari

pihak petugas bank syariah. Artinya, pelayanan yang diberikan oleh erbankan syariah harus mengutamakan pelayanan kenyamanan bagi nasabah. Kemudian, pelayanan berbasis syariah Islam, baik dalam proses komunikasi dan juga produk-produk perbankan syariah. Hal ini sangat 
penting dilakukan untuk menjaga nama baik dan reputasi perbankan syariah. Muamalah yang sama juga dilakuan kepadapara stakeholders, yaitu bermuamalah pada tatara operasioal daan kebijakan yang dikelola pihak lain. Para stakeholders ini dinilai sebagai mitra yang akan mendukung kinerja perbankan syariah dan berjalan sesai dengan visi dan misi yang ditetapkan.

Di sisi lain disjelaskan juga bahwa tujuan pertama didirikan perbankan syariah adalah hadirnya kesadaran masyarakat muslim untuk menjalankan perputaran roda keuangan berdasarkan konsep Al-Quran dan Sunnah (Wardayati, 2011). Terdapat 5 konsep ajaran Islam yang diterapkan dalam praktik perbankan syariah, yaitu keterbukaan (tranparency), akuntabilitas (accountability), tanggung jawab (responsibility), independensi (independency), dan keadilan (fairness) (Wardayati, 2011). Kelima prinsip ini disebut sebagai bagian dari good corporate governance (GCG) yang prinsip tata kelola perbankan. GCG juga dikenal sebagai sebuah peraturan yang digunakan untuk mengelola dan mengatur hubungan antar pihak berkepentingan di dalam suatu peruusahaan. Oleh karena itu, pelayanan yang diberikan kepada nasabah dan kepada semua pihak yang menggunakan jasa perbankan syariah harus diperlakukan sebaik mungkin sesuai dengan prinsip di atas.

\section{Simpulan}

Dari penjelasan tulisan ini, dapat penulis simpulkan bahwa perkembangan teknologi informasi menjadi hal penting yang perlu dipertimbangkan dengan baik. Salah satu sektor terpenting di era Revolusi Industri 4.0 ini adalah dengan memadukan proses pemanfaatn teknologi informasi dengan sistem perbankan, baik itu perbankan konvensional dan syariah. Namun, perbankan syariah dinilai masih sedikit lambat dengan kinerja perbankan lainnya, sehingga perbankan syariah perlu untuk menerapkan kebijakan-kebijakan khusus terkait penggunaan teknologi informasi. Hal ini dilaksanakan dengan harapan dapat meningkatkan mutu pelayanan dan menjaga ketahanan nasabah.

Oleh karena itu, demi terwujdnya sistem perbankan syariah yang lebih efisien, penulis mencoba untuk merekomendasikan beberapa langkah, pertama, peningkatan strategi sosialisasi digital. Langkah ini disesuaikan dengan kehidupan masyarakat yang telah menggunakan gadget, khususnya kalangan milenial. Kedua, merancang produk bank syariah yang lebih energik, milenial dan mengandung nilai-nilai Islami. Ketiga, membangun kerjasama dengan sejumlah mitra anak muda milenial Muslim. Saran-saran tersebut peulis rekomendasikan meningat anak muda milenial saat ini tidak sedikit yang telah memanfaat gadget untuk menghasilkan uang. Dan tidak sedikit dari mereka yang mencoba menginvestasikan dana yang dimiliki di berbeagai bidang. Dengan demikian, langkah ini menjadi salah satu yang perlu dipertimbangkan lebih mendalam dari pihak perbankan syariah.

\section{Referensi}

Alamsyah, D. H. (2012). Perkembangan dan Prospek Perbankan Syariah Indonesia: Tantangan Dalam Menyongsong MEA 2015. Retrieved from https://www.bi.go.id/id/ruangmedia/pidato-dewan-gubernur/Pages/TantanganDalamMenyongsongMEA2015_HA.aspx

Apriyanti, H. W. (2018). Perkembangan Industrei Perbankan Syariah di Indonesia: Analisis 68 
Peluang dan Tantangan. Jurnal Maksimum Media Akuntansi, 8(1), 16.

Ayufi, N., Pertiwi, R., Shabrina, V. G., \& Irwansyah. (2019). Pemanfaat Co-Creation oleh Jenis Co.Create sebagai Strategi Pengembangan Produk Perbankan Digital Jenius. Petanda: Jurnal Ilmu Komunikasi Dan Humaniora, 1(2), 52.

Budiono, A. (2017). Penerapan Prinsip Syariah Pda Lembaga Keuangan Syariah. Jurnal Law and Justice, 2(1), 69.

Dz, A. S. (2018). Inklusi Keuangan Perbankan Syariah Berbasis Digital-Banking: Optimalisasi dan Tantangan. Jurnal Al-Amwal, 10(1), 63.

Fatahillah, H. H. (2018). Digital Economy, Digital Banking dan Islam Bank. Retrieved July 25, 2020, from https://pkebs.feb.ugm.ac.id/2018/03/15/digital-economy-digital-banking-danislamic-bank/

Fatimah, S. B., \& Hendratmi, A. (2020). Digitalisasi Pada Bank Mandiri Syariah di Tengah Persaingan dan Perubahan Teknologi. Jurnal Ekonomi Syariah, 7(2), 795.

Fatimah, S., \& Suib, M. S. (2019). Transformasi Sistem Pembayaran Pesantren Melalui EMoney Digital. Jurnal Ekobis, 2(2), 96.

Franedya, R. (2018). Ini Dia Empat Jenis FinTech di Indonesia. Retrieved July 25, 2020, from CNBC Indonesia website: https://www.cnbcindonesia.com/tech/20180110145800-371126/ini-dia-empat-jenis-fintech-di-indonesia

Haryanto, A. T. (2019). Pengguna Internet Indonesia didominasi Milenial. Retrieved July 26, 2020, from Detik.com website: https://www.bi.go.id/id/tentang-bi/fungsibi/tujuan/Contents/Default.aspx

Hutauruk, D. M. (2020). Bank Syariah Mulai Menuai Hasil dari Transformasi Digital. Retrieved July 25, 2020, from https://keuangan.kontan.co.id/news/bank-syariah-mulai-menuai-hasildari-transformasi-digital

Indonesia, B. (2020). Fungsi dan Tugas BI. Retrieved July 26, 2020, from Bank Indonesia website: https://www.bi.go.id/id/tentang-bi/fungsi-bi/tujuan/Contents/Default.aspx

Itg.id. (2019). Jenis FinTech. Retrieved July 25, 2020, from Itg.id website: https://itgid.org/jenisfintech/

Jayani, D. H. (2019). Berapa Pengguna Internet di Indonesia. Retrieved July 26, 2020, from Katadata.co.id website: https://databoks.katadata.co.id/datapublish/2019/09/09/berapapengguna-internet-di-indonesia

Kusnandar, V. B. (2019). Indonesia Pengguna Internet Terbesar Ketiga di Asia. Retrieved July 26, 2020, from Katadata.co.id website: https://databoks.katadata.co.id/datapublish/2019/07/18/indonesia-pengguna-internetterbesar-ketiga-di-asia

Okyanta, H. (2017). Analisis Penilaian Tingkat Kesehatan Bank Syariah dengan Metode Ibadah, Muamalah, Amanah, Ihsan (Iman). Jurnal Akuntansi Aktual, 4(2), 140.

Perbankan, L. S. P. (2018). Menyiapkan Kompetensi Bankir di Era Disrupsi Teknologi Finansial. Jakarta Selatan.

Putritama, A. (2018). Penerapan Etika Bisnis Islam Dalam Industri Perbankan Syariah. Jurnal Nominal, $\operatorname{VII}(1), 1$.

Rianto, M. R., Bukhari, E., \& Fikri, A. W. N. (2020). Ancaman Pola Perilaku Finansial Teknologi terhadap Eksistensi Industri Perbankan di Indonesia. Jurnal Ilmiah Akuntansi Dan Manajemen (JIAM), 16(1), 27.

Rohayati. (2019). Aktifitas Bisnis Perbankan Syariah Dalam Perspektif Komunikasi Dakwah. Jurnal Idarotuna, 2(1), 34. 
Sudarwan, I. A. (2019). OJK Rancang 2 Skema Kerjasama Bank Syariah dan Fintech. Retrieved July 24, 2020, from Bisnis.com website: https://finansial.bisnis.com/read/20190121/90/880822/ojk-rancang-2-skema-kerja-samabank-syariah-dan-fintech

Syukron, A. (2013). Dinamika Perkembangan Perbankan Syariah di Indonesia. Economic: Jurnal Ekonomi Dan Hukum Islam, 3(2), 29.

Tazkiyyaturrohmah, R., \& Sriani, E. (2020). Peluang dan Tantangan Bank Syariah di Era Industri 4.0. Transformasi: Jurnal Studi Agama Islam, 13(1), 74.

Utama, A. S. (2018). Sejarah dan Perkembangan Regulasi Mengenai Perbankan Syariah Dalam Sistem Hukum Nasional di Indonesia. Jurnal Wawasan Yuridika, 2(2), 190.

Wardayati, S. M. (2011). Implikasi Shariah Governance Terhadap Reputasi dan Kepercayaan Bank Syariah. Walisongo, 19(1), 9.

Winasis, S., \& Riyanto, S. (2020). Transformasi Digital di Industri Perbankan Indonesia: Impak Pada Stress Kerja Karyawan. Istishadia: Jurnal Ekonomi Dan Perbankan Syariah, 7(1), 56. 